\title{
Paleomagnetism and Post-Middle Miocene Counter-Clockwise Rotation of Tanegashima Island off Kyushu, Japan
}

\author{
Kazuto Kodama ${ }^{1}$, Tomowo Ozawa ${ }^{2}$, Keisuke Inour ${ }^{2}$, \\ Yoshiaki MAEDA $^{1}$, and Tohru TAKEUCHI ${ }^{2}$ \\ ${ }^{1}$ Department of Geology, Kochi University, Kochi 780, Japan \\ ${ }^{2}$ Department of Earth Sciences, Nagoya University, Nagoya 464, Japan
}

(Received February 12, 1991; Revised May 17, 1991)

\begin{abstract}
A paleomagnetic study was carried out on sedimentary rocks from the Middle Miocene Kukinaga Group and the Paleogene Kumage Group in Tanegashima Island off the southern extremity of Kyushu. 173 specimens were collected from 15 stratigraphic levels of the Kukinaga Group and 113 from seven horizons of the Kumage Group. After thermal and alternating field demagnetizations, characteristic magnetization directions were determined using the combined analysis of direct line-fitting and demagnetization plane data. Reliable paleomagnetic directions were isolated for 11 horizons from the Kukinaga Group. Eight of these were of reversed polarity and the remaining three from the uppermost horizons were of normal polarity. The unfolded formation-mean direction was $\mathrm{D}=331.2^{\circ}, \mathrm{I}=41.3^{\circ}$, and $\alpha_{95}=9.9^{\circ}$. Five horizons of the Kumage Group yielded stable magnetization components of reversed polarity which, however, were not regarded as primary because of the negative tilt test. The mean paleomagnetic direction for the Kukinaga Group is deflected westward from the direction predicted using the $10 \mathrm{Ma}$ paleopole of Eurasia by $33.0^{\circ} \pm 10.7^{\circ}$. This implies that Tanegashima Island rotated counter-clockwise about $30^{\circ}$ with respect to Eurasia and Southwest Japan since the Late Miocene, probably during the last $10 \mathrm{Ma}$.
\end{abstract}

\section{Introduction}

A rapid increase in reliable paleomagnetic data, combined with well-documented geochronological evidence for the Tertiary rocks in the Japanese arc, has substantiated that Southwest Japan suffered a clockwise $(\mathrm{CW})$ rotation through $50^{\circ} \sim 60^{\circ}$ in the early Middle Miocene (OtofuJi and Matsuda, 1983; Hayashida and Ito, 1984; OTOFuJI et al., 1985a; HAYASHIDA, 1986). In contrast, Northeast Japan experienced a counterclockwise (CCW) rotation (ОTOFUJI et al., 1985b) which seems to predate slightly the CW rotation of Southwest Japan (Tosha and Hamano, 1988; YAmAZAKI, 1989). It has generally been accepted that the differential rotation between Southwest Japan and Northeast Japan resulted from the breakup of Asian continental margin and subsequent back-arc spreading of the Japan Sea in Miocene time (OTOFUJI et al., 1985c; OTOFUJI and MATSUdA, 1987).

As most of the paleomagnetic data were derived from the western part of Honshu Island, there is a controversy concerning the position of the tectonic boundary of the part of Southwest Japan block (HIROOKA et al., 1986; IтоH, 1988; IsHIKAWA et 
al., 1989). We will use hereafter the term "Southwest Japan block" as a single, rigid, tectonic unit characterized by $\mathrm{CW}$ deflected paleomagnetic directions. Paleomagnetic data from Kyushu and Shikoku Islands are still insufficient to clarify the tectonic history of these regions. Paleomagnetic directions are available only from the Cretaceous sedimentary rocks in Shikoku Island (KodAma et al., 1983; KodAma, 1989, 1990) and from the Cretaceous to Tertiary granitic and sedimentary rocks in Kyushu Island (ITO et al., 1980; Iто and ToKiedA, 1986; KodAmA and BABA, 1988). The Cretaceous paleomagnetic declinations from Shikoku (KoDAmA, 1990) and northern Kyushu (Iто and TOKIEDA, 1986) show a CW deflection, in the same manner as reported from Honshu. In contrast, paleomagnetism of the Tsushima Islands (IsHIKAWA et al., 1989) and Goto Islands (ITO et al., 1980; IsHIKAWA and TAGAMI, 1991) off northern Kyushu suggested a Middle Miocene CCW rotation for the islands. The discrepancy in declination may imply that the tectonic boundary of the Southwest Japan block runs somewhere between northern Kyushu and those islands. The pre-Miocene strata in Southwest Kyushu show a distinct southward bend from the typical ENE-WSW strike of Southwest Japan (Murata, 1987; Yoneda and Iwamatsu, 1987); Hashimoto (1962) has named this structure the "Hokusatsu Bending" after its locality. The complex geological structure and the lack of reliable paleomagnetic data from South Kyushu make it impossible to define the western margin of the Southwest Japan block.

This study deals with paleomagnetism of sedimentary rocks in Tanegashima Island, about $40 \mathrm{~km}$ southwest of the southern extremity of Kyushu (Fig. 1). In remarkable contrast to Yakushima Island to the west, which is composed chiefly of a huge granitic rock body of Miocene age, Tanegashima Island consists of thick Tertiary sedimentary rocks (e.g., HAYASAKA, 1988). The structural trend of these rocks continue to southeast Kyushu. We carried out a paleomagnetic study aimed at clarifying whether Tanegashima Island belongs to the Southwest Japan block and, if not, examining the possible tectonic rotation of South Kyushu, including Tanegashima Island, with respect to Eurasia or Honshu main island.

\section{Geology}

Tanegashima Island is overlain dominantly by the Paleogene Kumage Group, which belongs to the Shimanto Supergroup in the outer zone of Southwest Japan (e.g., TAIRA et al., 1982), and the Miocene Kukinaga Group (Fig. 1). The Kumage Group, exposed in the northern and southwestern parts of this island, consists of alternating layers of sandstone and shale dipping northwestward at high angles about NNE-SSW strike. The Kumage Group is subdivided into four lithostratigraphic units; the Nijuban, Hamatsuwaki, Fukago and Sumiyoshi Formations, in ascending order (HAYASAKA et al., 1980; Fig. 2). The total thickness is more than $5000 \mathrm{~m}$. Radiolarians of the Middle to Late Eocene were reported from the varicolored shales interbedded in sandstoneshale alternations of the Hamatsuwaki and Nijuban Formations (OKADA et al., 1982). Bedded sandstones of the Hamatsuwaki and Fukago Formations yielded several molluscan fossils similar to those found in the Late Oligocene to Early Miocene Asiya Group in North Kyushu (HAYASAKA et al., 1980).

The Kukinaga Group overlies the Kumage Group with angular unconformity and is found in the southern part of the island. The strata dip eastward $10^{\circ} \sim 20^{\circ}$ about a N-S strike with a total thickness of $1500 \mathrm{~m}$ approximately. The Kukinaga Group 


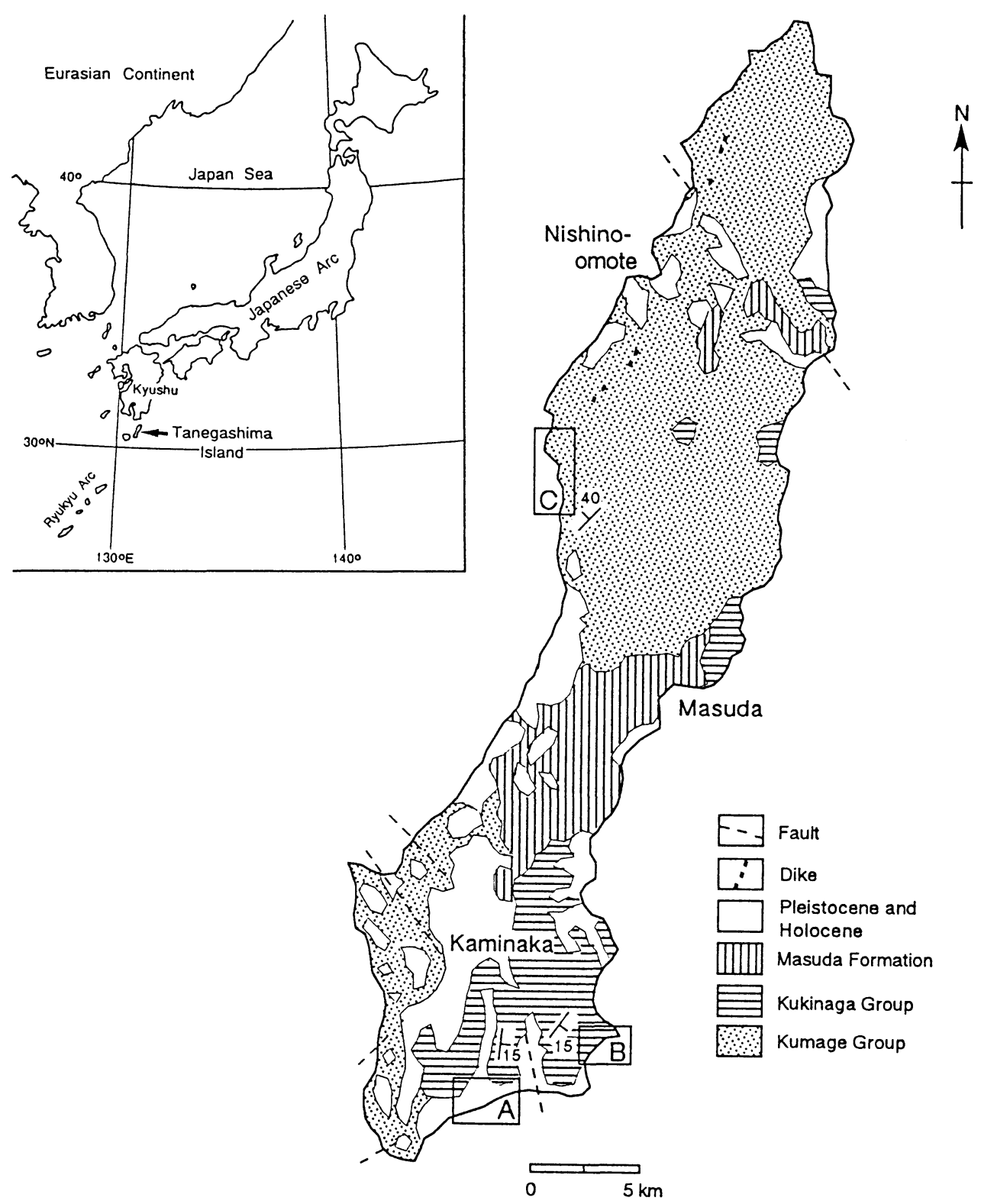

Fig. 1. Index map (inset) and general geology of Tanegashima Island (simplified in part after HAYASAKA, 1988). Boxes A, B, C are areas where paleomagnetic samples were taken. A, B; Kukinaga Group, C; Kumage Group. 


\begin{tabular}{|c|c|c|c|}
\hline AGE & \multicolumn{2}{|c|}{ GEOLOGIC SYSTEM } & $\begin{array}{c}\text { THICKNESS } \\
(\mathrm{m})\end{array}$ \\
\hline \multirow{2}{*}{ Pleistocene } & \multicolumn{2}{|c|}{ Takenokawa F. } & $<10$ \\
\hline & \multicolumn{2}{|c|}{ Hase F. } & $<10$ \\
\hline \multirow[t]{2}{*}{ Pliocene } & \multicolumn{2}{|c|}{$\begin{array}{l}\text { Masuda F. } \\
\text { neonformity }\end{array}$} & \\
\hline & \multirow{3}{*}{ 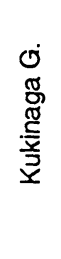 } & Osaki F. & 700 \\
\hline \multirow{2}{*}{$\begin{array}{l}\text { Middle } \\
\text { Miocene }\end{array}$} & & Kawachi F. & 300 \\
\hline & & Tashiro F. & 400 \\
\hline \multirow{4}{*}{$\begin{array}{l}\text { Eocene to } \\
\text { Oligocene }\end{array}$} & \multirow{4}{*}{ 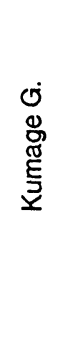 } & Sumiyoshi F. & 600 \\
\hline & & Fukago F. & 1600 \\
\hline & & Hamatsuwaki F. & 1400 \\
\hline & & Nijuban F. & $>1000$ \\
\hline
\end{tabular}

Fig. 2. Stratigraphy of Tanegashima Island (synthesized after HAYASAKA et al., 1980 and HAYASAKA, 1988).

is subdivided into the Tashiro, Kawachi and Osaki Formations, in ascending order (HAYASAKA, 1969; Fig. 2). The Tashiro Formation represents a basal facies consisting of conglomerates originated from the Kumage Group. The Kawachi Formation consists of thick layers of mudstone and siltstone intercalated with thin sandstone beds. The Osaki Formation consists of coarse to medium grained sandstone layers. Except for the Tashiro Formation, the overlying two formations are rich in characteristic marine molluscs of the Kadonosawa Fauna, found widely in the early Middle Miocene deposits in the Japanese Islands (HAYASAKA, 1969). A limited occurrence of a planktonic foraminifera assemblage from the uppermost part of the Osaki Formation suggests the Zones N14 to N18 of BLOW (1969), corresponding to the late Middle Miocene to the earliest Pliocene (HATTA, 1988). One of the authors (K.I.) recently found a similar planktonic foraminifera assemblage from the same uppermost horizon of the Osaki Formation, which gives a little better age constraint, consisting of Blow's Zone N13 to N15, correlative to the late Middle Miocene. Thus, the age of the Kukinaga Group could be the early Middle to late Middle Miocene, probably between $10 \mathrm{Ma}$ and 15 Ma. Plio-Pleistocene deposits overly in part the Kumage and Kukinaga Groups. A 5 to $10 \mathrm{~m}$ thick alkaline dike runs a few kilometers inland along the northwestern coast of the island. The K-Ar age of this dike is $16 \pm 2 \mathrm{Ma}$ (TANEDA and KinOSHITA, 1972). 


\section{Sampling, Measurements and Analysis}

All the samples were drilled in the field using a portable gasoline-powered drill with a $25 \mathrm{~mm}$ inside diameter coring bit. Each sample, oriented with a magnetic and/or a sun compass, was sliced into $22 \mathrm{~mm}$ long core specimens. To minimize the effects of surface weathering, one specimen from the deepest portion of each core sample, or two if long enough, was used for the measurements. In the Kukinaga Group, 173 specimens were collected from layers of mudstone or fine-grained sandstone at 15 different stratigraphic levels, with 10 sites from the Kawachi Formation and five sites from the uppermost horizons of the Osaki Formation. Because of 10 to $30 \mathrm{~cm}$ deep surface weathering of the Kukinaga Group, 6 to 11 samples were drilled from one layer at each site after removal of such weathered portions. In the Kumage Group, 113 specimens were taken from five sites in the Fukago Formation and two sites from the Sumiyoshi Formation, where alternating strata of sandstone and shale are well exposed. Samples were collected at sites displaying different bedding attitudes suitable for a fold test. At each locality, 9 to 12 samples were taken from 3 to $10 \mathrm{~cm}$ thick sandstone-shale alternations with 2 to 5 samples per layer. No sample was taken from the Plio-Pleistocene Masuda Formation which consists of loose and weathered sandstone. Bedding attitudes were measured on several surfaces and averaged at each sampling locality, giving an error estimate of two or three degrees. Localities and stratigraphic levels of the sites are shown in Figs. 1 and 3.

Magnetization measurements were performed on a three-axis $2 \mathrm{G}$ cryogenic magnetometer (2G Model $760 \mathrm{R}$ ) with an automated sample handler using five orientations per specimen. The noise level in magnetic moment was $3 \times 10^{-6}$ to $5 \times 10^{-6} \mathrm{~A} / \mathrm{m}$. Thermal demagnetization was made in air in a laboratory-made furnace settled in a three-layered $\mu$-metal magnetic shield, in which the ambient field intensity is less than $10 \mathrm{nT}$. Progressive thermal demagnetization was made in steps from $100^{\circ} \mathrm{C}$, with $25^{\circ}$ increments, until the magnetization intensity became too weak for meaningful measurement, or until acquisition of viscous remanent magnetization (VRM), expressed by an up to one order of magnitude increase in intensity or magnetic susceptibility, was encountered. Bulk magnetic susceptibility was measured for selected pilot specimens after each thermal treatment with a Bartington susceptibility meter (Model M.S.2) in order to monitor thermal alteration of magnetic minerals likely to occur at higher temperatures. AF demagnetization was accomplished on a demagnetizer consisting of a three-axis sample tumbler, AC oscillator and low distortion audio-amplifier, with 50 $\mathrm{mT}$ maximum field intensity. Progressive af demagnetization was made in steps from 2.5 to $25 \mathrm{mT}$ with $2.5 \mathrm{mT}$ increments, and 30 to $45 \mathrm{mT}$ with $5 \mathrm{mT}$ increments. This was followed by additional thermal demagnetization at $100^{\circ} \mathrm{C}$ to $350^{\circ} \mathrm{C}$ if required. As a pilot study, at least one pair of specimen was prepared from a long core sample at individual sites, and each companion specimen was subjected to af or thermal demagnetization to determine the effective demagnetization for the remainders.

Magnetization vectors after demagnetization were projected on a Zijderveld diagram (ZIJDERVELD, 1967) for each specimen. The characteristic magnetizations were isolated by applying the three-dimensional least-squares line fit of KIRSCHVINK (1980) to those sets of vectors which displayed a linear trend on the diagram. Those directions defined by a minimum of four vector endpoints with a MAD (Maximum Angular Deviation of KIRSCHVINK (1980)) of less than $15^{\circ}$ were employed for further data analyses. 
Some specimens, although overprinted in different ways, seemed to share a common magnetic component. If the common direction could not be identified solely by a direct line-fit, the least-squares demagnetization plane analysis combined, if available, with direct line-fit observations (MCFADDEN and MCELHINNY, 1988) was applied to estimate the hidden common component and associated Fisher statistics. Each demagnetization plane was defined by a set of at least three vector endpoints including, if necessary, the NRM point. The statistical significance of a regional fold test for the Kumage Group was determined by the method of MCFADDEN and Jones (1981).

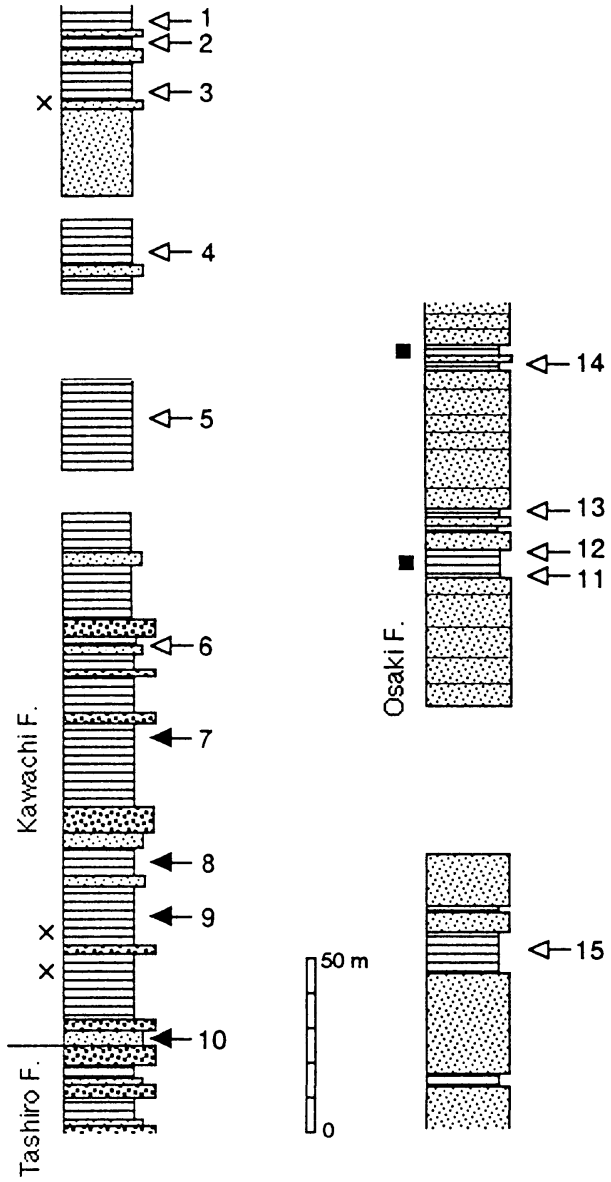

Kukinaga Group

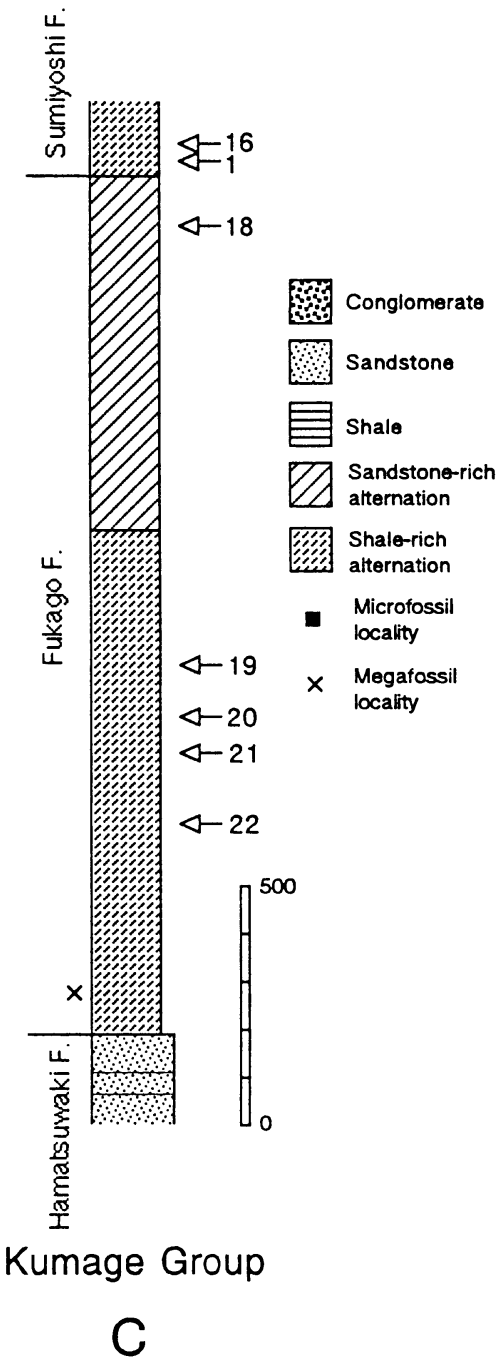

A

B

Fig. 3. Columnar sections and stratigraphic levels of sampling sites in the three areas $(A, B, C)$ in Fig. 1. Solid (open) arrows denote sampling horizons of normal (reversed) polarity. The attached numbers are names of sampling sites. Horizons of microfossil (planktonic foraminifera) and megafossil localities are also shown. 


\section{Paleomagnetic Results}

\subsection{Kukinaga Group}

NRM intensities from the Kukinaga Group samples were very weak, between $7.8 \times 10^{-8}$ and $7.1 \times 10^{-6} \mathrm{kA} / \mathrm{m}(1 \mathrm{kA} / \mathrm{m}=1 \mathrm{emu} / \mathrm{cc})$, typically ranging from $3 \times 10^{-7}$ to $5 \times 10^{-7} \mathrm{kA} / \mathrm{m}$ as summarized in Fig. 4 . Of the 173 specimens prepared, 140 specimens were thermally demagnetized at temperatures from $100^{\circ} \mathrm{C}$ to $300^{\circ} \mathrm{C}$ or $325^{\circ} \mathrm{C}$ above which most of the specimens exhibited a rapid increase in magnetic intensity and/or unstable directionality. The remaining 33 specimens were af demagnetized and showed moderate magnetic coercivities with mean destructive field (MDF) intensities of 7.5 to $20 \mathrm{mT}$. Examining the linearity of endpoints of demagnetized vectors on orthogonal projections, characteristic magnetization directions were isolated for 19 specimens from six sites (sites 2, 3, 4, 7, 9, 10), 15 specimens of which were thermally demagnetized. Examples of the orthogonal projections are shown in Fig. 5. No reliable line-fit directions were obtained from the remaining specimens because of either too weak intensities or scattered directions at higher demagnetization levels. However, 88 specimens yielded demagnetization great circles defined by at least three endpoints of magnetization with low to moderate coercivity. Those demagnetization plane data, combined with the direct line data, were used to calculate site-mean directions by the method of MCFADDEN and MCELHINNy (1988). With this method, site-mean directions were estimated for the eight sites ( $\operatorname{sites} 5,6,8,11-15)$, where no line-fit data were available, but where their polarities could be inferred by the trend of directional change during stepwise demagnetizations. Examples of the analysis are illustrated in Fig. 6. Site-mean directions from three sites (sites 8, 13, 15) were omitted from later computation for between-site mean direction because of their large semi-angle of confidence cones $\left(\alpha_{95}\right)$ in excess of $20^{\circ}$. No reliable line or plane data were obtained from site 1 .
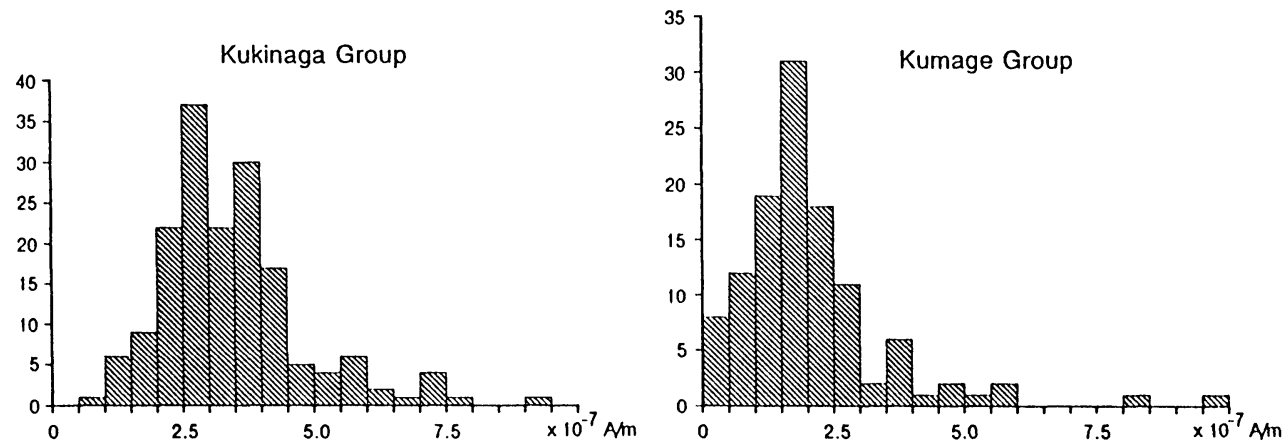

Fig. 4. Frequency distribution of initial NRM intensity for the Kukinaga (left) and Kumage (right) Groups. 
K. KodAmA et al.

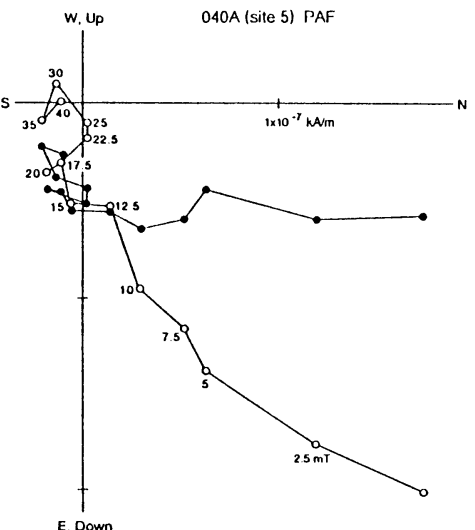

A

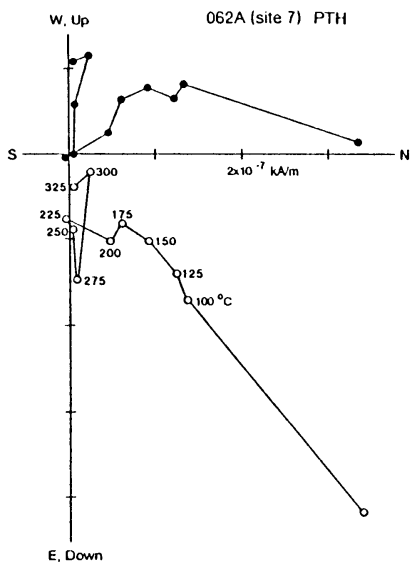

C

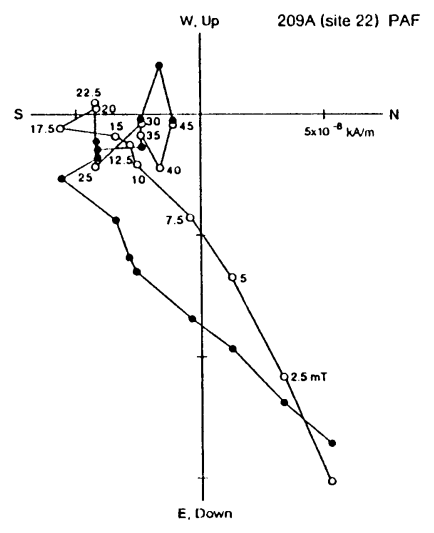

E

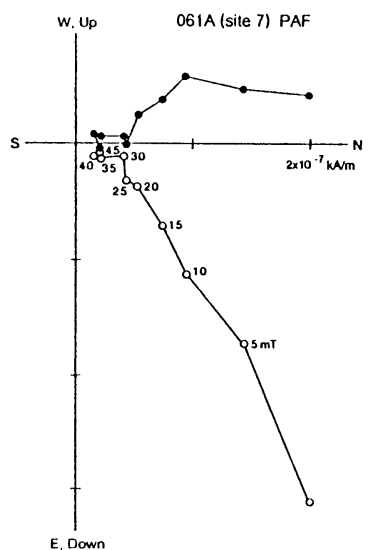

B

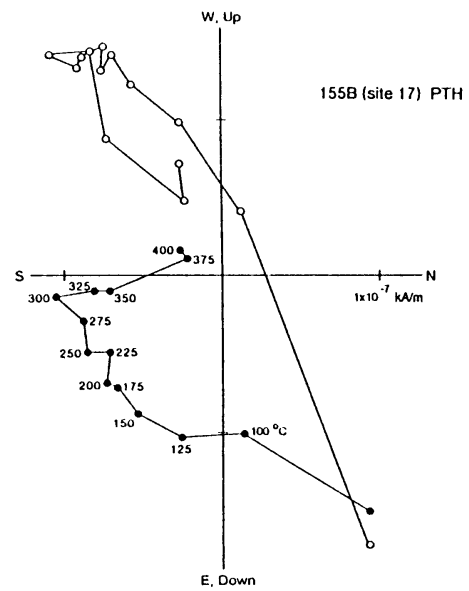

D

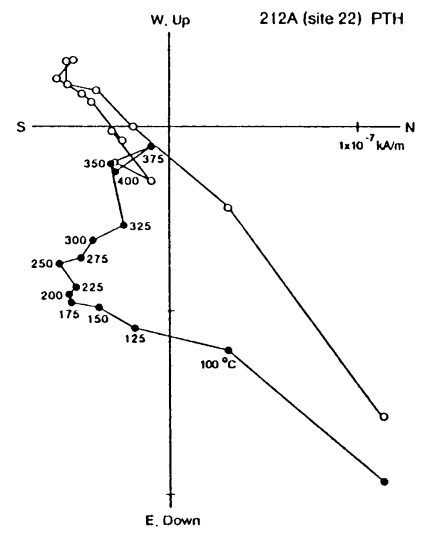

$\mathrm{F}$

Fig. 5 
Of the 11 sites selected, three sites (sites 7, 9, 10) from horizons of the lower Kawachi Formation displayed normal polarity and the other eight sites were of reversed polarity (Fig. 3). Samples with normal polarity from sites 11, 12 and 14 were collected from the uppermost horizons of the Osaki Formation, which yielded a planktonic foraminiferal assemblage of the late Middle Miocene in age (N13 to N15 in the Blow's zonation) as mentioned in the geology section above. The lack of successive polarity records and poor biostratigraphic information for the entire Kukinaga section make it impossible to assign those polarities to specific polarity chrons in the Middle Miocene. However, the detection of mixed polarities from the entire Kukinaga Group enhances the reliability of these paleomagnetic results.

Results from the line and plane data analysis are summarized in Table 1 . The sitemean directions before and after correction for bedding tilt are plotted in Fig. 7 . The mean direction for the eight tilt-corrected directions of reversed polarity was $\mathrm{D}=146.4^{\circ}$, $\mathrm{I}=-41.2^{\circ}$ with $\alpha_{95}=12.7^{\circ}$, and that of normal polarity was $\mathrm{D}=343.4^{\circ}, \mathrm{I}=40.7^{\circ}$ with $\alpha_{95}=19.0^{\circ}$. The two mean directions are in antipodal relationship on the $95 \%$ confidence level. The overall mean of those sites after converting the reversed directions to the normal was $\mathrm{D}=331.2^{\circ}, \mathrm{I}=41.3^{\circ}$, and $\alpha_{95}=9.9^{\circ}$. No better grouping of statistical significance in site-mean directions was found upon applying tilt correction because the bedding attitude of the Kukinaga Group is not so variable to allow a conventional folding test. However, the directions of both normal and reversed polarity and their antipodal relationship, along with the definite deflection from the present geomagnetic field direction, suggest that those directions represent primary detrital magnetizations acquired prior to bedding tilt.

Application of least-squares line and plane analysis to paleomagnetic data from the two Groups enabled us to not only estimate magnetization components with higher unblocking or coercivity spectra, but to extract components removed during early steps of af or thermal demagnetization. Directions of the soft components were computed

Fig. 5. Examples of Zijderveld demagnetization diagram. Solid and open circles are projections on the horizontal and the vertical north-south plane, respectively, in situ coordinate. PAF; progressive alternating field demagnetization, PTH; progressive thermal demagnetization. A, lower Kawachi Formation of the Kukinaga Group. Due to the erratic behavior of vectors at steps above $25 \mathrm{mT}$, a demagnetization great circle obtained by least-squares plane fit of the NRM through 25 $\mathrm{mT}$ steps was used to compute the stable vector endpoint. Probably reversed polarity. B, lower Kawachi F. Normal polarity with characteristic direction $\left(\mathrm{D}=322.6^{\circ}, \mathrm{I}=47.7^{\circ}, \mathrm{MAD}=11.4^{\circ}\right)$ obtained by least-squares line fit using $10 \mathrm{mT}$ through $40 \mathrm{mT}$ steps. Low coercivity component with direction $\left(\mathrm{D}=8.2^{\circ}, \mathrm{I}=63.1^{\circ}, \mathrm{MAD}=4.4^{\circ}\right)$ from the NRM through $10 \mathrm{mT}$ steps is recognized as a present field overprint. $\mathbf{C}$, the same horizon as $\mathrm{B}$ in lower Kawachi F. Normal polarity with characteristic direction $\left(\mathrm{D}=317.8^{\circ}, \mathrm{I}=8.6^{\circ}, \mathrm{MAD}=14.4^{\circ}\right)$ from $150^{\circ}$ through $225^{\circ}$ steps. Low temperature component with direction $\left(\mathrm{D}=16.2^{\circ}, \mathrm{I}=51.0^{\circ}, \mathrm{MAD}=3.6^{\circ}\right)$ from the $\mathrm{NRM}$ through $125^{\circ}$ steps is probably a present field overprint. D, lower Sumiyoshi Formation of the Kumage Group. Reversed polarity with characteristic direction $\left(\mathrm{D}=160.9^{\circ}, \mathrm{I}=-48.8^{\circ}, \mathrm{MAD}=13.0^{\circ}\right)$ from $300^{\circ}$ through $375^{\circ}$. Low temperature component with direction $\left(\mathrm{D}=29.8^{\circ}, \mathrm{I}=57.0^{\circ}, \mathrm{MAD}=10.4^{\circ}\right)$ is identified from the NRM through $275^{\circ}$ steps. E, lower Fukago F. of the Kumage Group. Because of the irregular manner above $15 \mathrm{mT}$, a demagnetization great circle was computed using steps from the NRM through $15 \mathrm{mT}$. Probably reversed polarity. F, the same site as E within lower Fukago F., but exhibits demagnetization trend more linear than $\mathrm{E}$ at higher steps. Reversed polarity with characteristic direction $\left(\mathrm{D}=118.9^{\circ}, \mathrm{I}=-34.2^{\circ}, \mathrm{MAD}=12.7^{\circ}\right)$ from $200^{\circ}$ through $375^{\circ}$ steps. Lower temperature component with direction $\left(\mathrm{D}=31.0^{\circ}, \mathrm{I}=43.9^{\circ}, \mathrm{MAD}=5.0^{\circ}\right)$ is identified from the NRM through $175^{\circ}$ steps. 


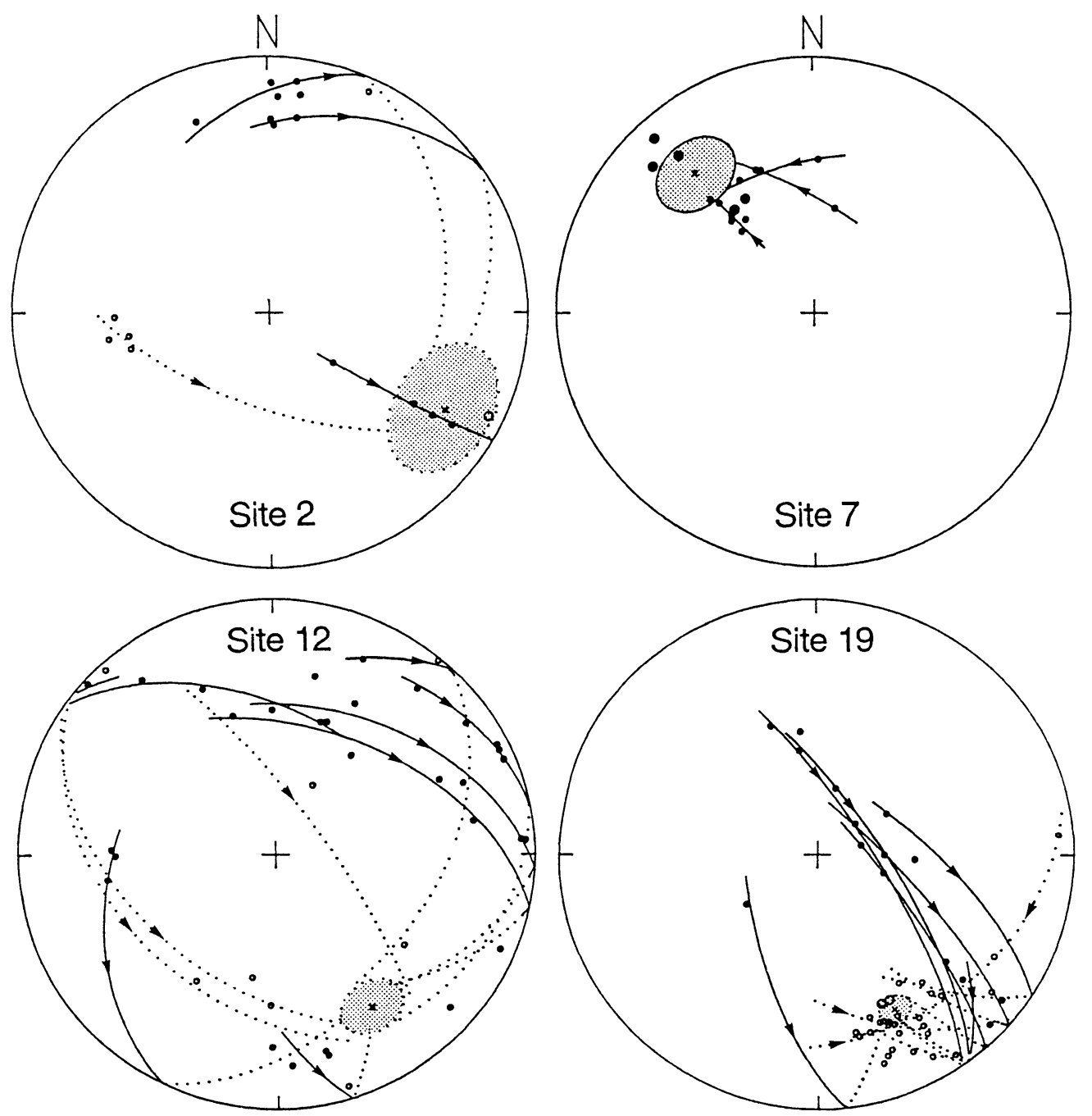

Fig. 6. Examples of the combined analysis of demagnetization great circles and direct observations by MCFAdDEn and McElhinny (1988). Sites 2, 7; lower Kawachi Formation of the Kukinaga Group. 12; upper Osaki Formation of the Kukinaga Group, 19; lower Fukago Formation of the Kumage Group. Equal-area projection with solid symbols on the lower hemisphere and dotted or open ones on the upper hemisphere. Solid (dotted) lines are the best-fit demagnetization great circle arcs on the lower (upper) hemisphere. Small circles along each great circle are directions of vectors used for the least-squares computation. Arrows represent sense of directional movement along the demagnetization path. Shaded ovals indicate $95 \%$ confidence error limit and cross marks within them denote the mean directions.

using at least three endpoints of vectors removed with a univectorial trend (MAD smaller than $15^{\circ}$ ). These components were isolated for 131 Kukinaga specimens, 19 of which had higher unblocking temperatures or coercivity components regarded as primary. All the directions of the low temperature or low coercivity components are plotted in Fig. 8. The mean direction of the in situ directions was $\mathrm{D}=349.9^{\circ}, \mathrm{I}=48.8^{\circ}$ 


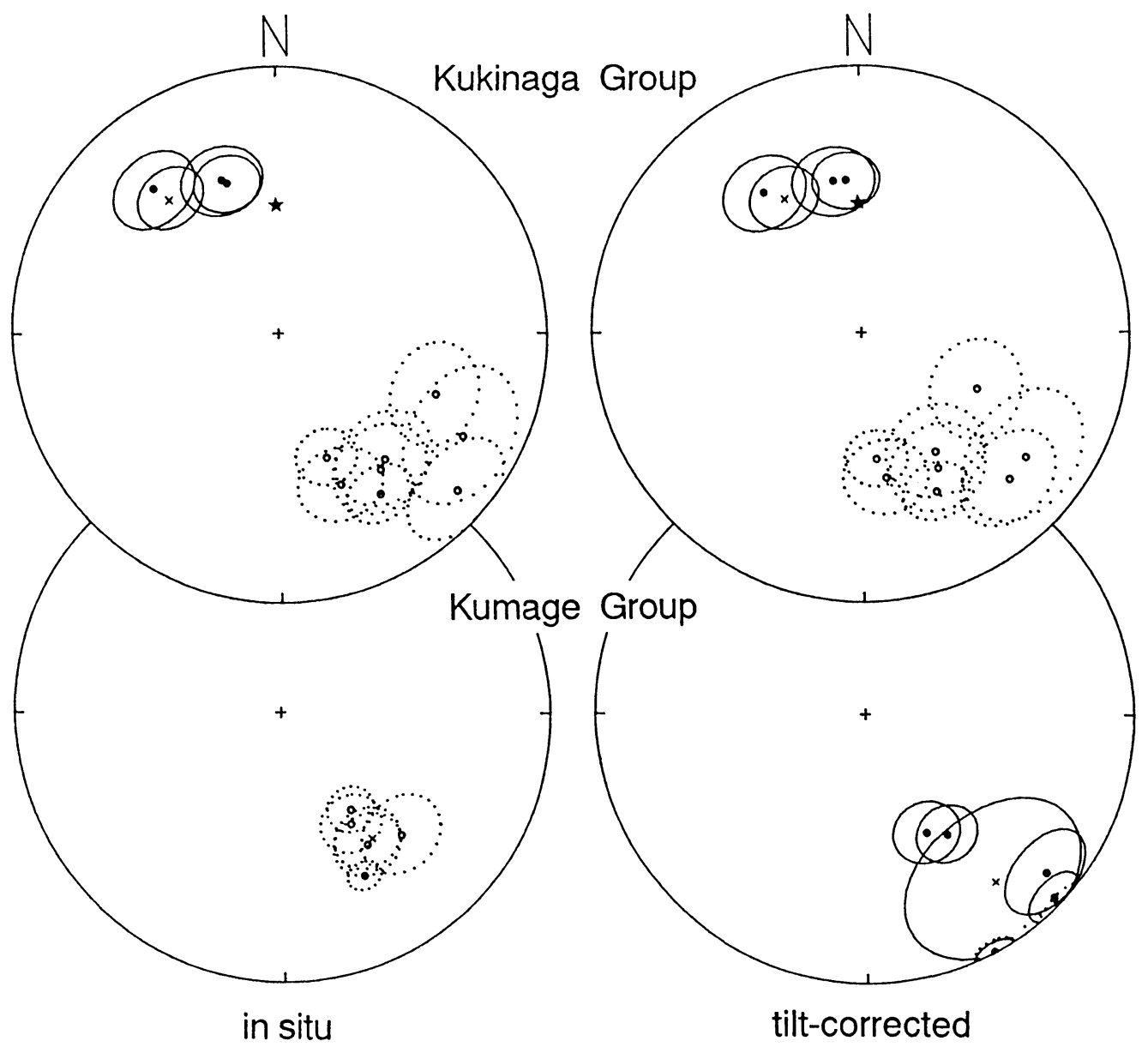

Fig. 7. Site-mean directions of the Kukinaga and Kumage Groups before (left) and after (right) tilt-correction. Equal-area projection with open circles and broken ovals for $95 \%$ confidence error on the upper hemisphere. Overall formation-mean directions are denoted by small cross marks with error ovals. Star indicates expected dipole field direction for Tanegashima Island.

with $\alpha_{95}=5.4^{\circ}$, which is statistically indistinguishable from the predicted axial dipole field direction. Upon structural correction at individual sites, the mean direction was $\mathrm{D}=4.3^{\circ}, \mathrm{I}=47.9^{\circ}$ and $\alpha_{95}=5.3^{\circ}$, which is also concordant with the dipole field direction. This seems to imply that the secondary components are the dipole field overprints acquired before or after tectonic tilt. 
Table 1. Summary of paleomagnetic results from Tanegashima Island.

\begin{tabular}{|c|c|c|c|c|c|c|c|c|}
\hline Site & $N(d, c)$ & Demag. range & $D$ & $I$ & $D^{*}$ & $I^{*}$ & $\kappa$ & $\alpha_{95}$ \\
\hline \multicolumn{9}{|c|}{ Kukinaga Group } \\
\hline 2 & $5(1,4)$ & $\begin{array}{r}125^{\circ}-200^{\circ} \\
\left(<175^{\circ}\right)\end{array}$ & 119.5 & -22.7 & 127.4 & -24.7 & 27 & 19 \\
\hline 3 & $7(4,3)$ & $\begin{array}{c}175^{\circ}-275^{\circ} \\
\left(<225^{\circ},<20 \mathrm{mT}\right)\end{array}$ & 131.6 & -12.9 & 135.1 & -23.9 & 21 & 14 \\
\hline 4 & $11(2,9)$ & $\begin{array}{c}125^{\circ}-175^{\circ}, 15-35 \mathrm{mT} \\
\left(<300^{\circ},<20 \mathrm{mT}\right)\end{array}$ & 140.2 & -38.9 & 148.6 & -46.8 & 12 & 14 \\
\hline 5 & $9(0,9)$ & $\left(<300^{\circ},<30 \mathrm{mT}\right)$ & 111.4 & -37.4 & 116.2 & -50.5 & 17 & 15 \\
\hline 6 & $5(0,5)$ & $\left(150^{\circ}-300^{\circ},<15 \mathrm{mT}\right)$ & 158.2 & -39.3 & 170.9 & -44.5 & 88 & 12 \\
\hline 7 & $8(5,3)$ & $\begin{array}{c}100^{\circ}-325^{\circ}, 10-40 \mathrm{mT} \\
\left(<300^{\circ},<10 \mathrm{mT}\right)\end{array}$ & 319.8 & 29.3 & 326.1 & 36.5 & 23 & 12 \\
\hline 8 & $4(0,4)$ & $\left(<300^{\circ},<12.5 \mathrm{mT}\right)$ & 355.2 & 32.8 & 3.1 & 33.0 & 27 & 35 \\
\hline 9 & $8(5,3)$ & $\begin{array}{c}<275^{\circ},<17.5 \mathrm{mT} \\
\left(<225^{\circ}\right)\end{array}$ & 340.5 & 38.6 & 350.4 & 41.6 & 25 & 12 \\
\hline 10 & $9(2,7)$ & $\begin{array}{c}150^{\circ}-275^{\circ} \\
\left(<300^{\circ},<20 \mathrm{mT}\right)\end{array}$ & 341.9 & 40.2 & 355.0 & 41.9 & 36 & 9 \\
\hline 11 & $9(0,9)$ & $\left(<225^{\circ},<20 \mathrm{mT}\right)$ & 159.5 & -49.2 & 173.8 & -50.9 & 44 & 9 \\
\hline 12 & $9(0,9)$ & $\left(<225^{\circ},<15 \mathrm{mT}\right)$ & 148.1 & -30.3 & 155.2 & -35.1 & 40 & 9 \\
\hline 13 & $5(0,5)$ & $\left(<200^{\circ},<25 \mathrm{mT}\right)$ & 148.0 & -33.1 & 154.2 & -37.9 & 24 & 23 \\
\hline 14 & $7(0,7)$ & $\left(<200^{\circ},<10 \mathrm{mT}\right)$ & 143.6 & -37.0 & 150.9 & -41.7 & 29 & 14 \\
\hline 15 & $7(0,7)$ & $\left(<200^{\circ},<25 \mathrm{mT}\right)$ & 146.3 & -41.1 & 160.4 & -41.5 & 10 & 24 \\
\hline & Mean & & 322.3 & 35.3 & 331.2 & 41.3 & 22 & 10 \\
\hline \multicolumn{9}{|c|}{ Kumage Group } \\
\hline 16 & $16(9,7)$ & $\begin{array}{c}175^{\circ}-400^{\circ}, 15-40 \mathrm{mT} \\
\left(<250^{\circ},<15 \mathrm{mT}\right)\end{array}$ & 196.1 & -29.0 & 177.7 & 13.4 & 3 & 25 \\
\hline 17 & $20(5,15)$ & $\begin{array}{c}200^{\circ}-400^{\circ} \\
\left(<250^{\circ},<30 \mathrm{mT}\right)\end{array}$ & 147.3 & -41.4 & 152.9 & 49.2 & 12 & 10 \\
\hline 18 & $10(2,8)$ & $\begin{array}{c}200^{\circ}-375^{\circ} \\
\left(<250^{\circ},<5 \mathrm{mT}\right)\end{array}$ & 148.3 & -49.9 & 145.9 & 45.5 & 34 & 9 \\
\hline 19 & $12(2,10)$ & $\begin{array}{c}225^{\circ}-350^{\circ} \\
\left(<350^{\circ},<15 \mathrm{mT}\right)\end{array}$ & 153.5 & -33.0 & 151.6 & -0.3 & 95 & 5 \\
\hline 20 & $16(10,6)$ & $\begin{array}{c}200^{\circ}-375^{\circ} \\
\left(<200^{\circ},<20 \mathrm{mT}\right)\end{array}$ & 144.7 & -53.8 & 134.3 & 3.5 & 30 & 7 \\
\hline 22 & $11(5,6)$ & $\begin{array}{c}200^{\circ}-375^{\circ} \\
\left(<300^{\circ},<15 \mathrm{mT}\right)\end{array}$ & 135.6 & -36.8 & 131.3 & 12.3 & 16 & 17 \\
\hline & Mean & & 145.9 & -43.1 & 142.3 & 22.1 & 10 & 25 \\
\hline
\end{tabular}

$N=$ number of specimens, $d=$ number of direct line-fit observations, $c=$ number of demagnetization great circles, Demag. range $=$ demagnetization range used for least-squares line and plane (in parenthesis) analysis, $D, I=$ in situ declination and inclination in degrees, $D^{*}, I^{*}=$ tilt-corrected declination and inclination in degrees, $\kappa=$ Fisher's precision parameter, $\alpha_{95}=$ radius of $95 \%$ confidence circle in degrees. $\kappa$ and $\alpha_{95}$ for overall mean directions were computed using tilt-corrected directions. Sites 8, 13, 15 in the Kukinaga Group, and site 16 in the Kumage Group were omitted for formation-mean computation due to large $\alpha_{95}$ in excess of $20^{\circ}$. 


\subsection{Kumage Group}

NRM intensities from the Kumage Group samples were slightly weaker than the Kukinaga Group samples and ranged from $1.8 \times 10^{-8}$ to $1.6 \times 10^{-6} \mathrm{kA} / \mathrm{m}$, with the majority between $1 \times 10^{-7}$ and $2.5 \times 10^{-7} \mathrm{kA} / \mathrm{m}$ (Fig. 4). According to pilot studies, excessive increases in both bulk magnetic susceptibility and magnetization intensity after heating above $350^{\circ} \mathrm{C}$ (Fig. 9) were observed more frequently than for the Kukinaga samples. These increases after thermal treatment suggest that magnetite was produced by oxidization of reduced phases of iron like pyrite and pyrrhotite. To avoid possible alteration of magnetic minerals, the remaining 100 specimens out of the total of 113 specimens were subjected to thermal demagnetizations at temperatures between $100^{\circ} \mathrm{C}$ and $350^{\circ} \mathrm{C}$, followed by one or two more steps if necessary. Orthogonal projections and principal component analysis of the demagnetized data yielded 33 characteristic magnetization components with higher unblocking or coercivity spectra. These characteristic magnetizations were accompanied by components that were unblocked lower than $200^{\circ} \mathrm{C}$, as in Fig. 5. Intensities of the low-temperature components computed by vector subtraction generally exceeded $50 \%$ of the initial NRM intensities. Demagnetization plane analysis applied to specimens with the additional components rendered 53 demagnetization great circles. Application of the McFadden and McElhinny's method to the line and plane data yielded five site-mean directions with $95 \%$ confidence errors less than $20^{\circ}$ (sites $17,18,19,20,22$ ). Two sites from the upper and lower Fukago Formations were excluded from between-site mean computation; site 16 for confidence error of greater than $20^{\circ}$ and site 21 for unstable magnetizations. In summary, in situ mean directions for the five sites, including sites 17 and 18 from the upper Fukago Formation and sites 19, 20, 22 from the lower Fukago Formation, displayed a cluster in the southeast quadrant of the upper hemisphere projection (Fig. 7).

An overall mean for the five in situ mean directions, with errors lower than $20^{\circ}$, was $\mathrm{D}=145.9^{\circ}, \mathrm{I}=-43.1^{\circ}$ and $\alpha_{95}=9.6^{\circ}$. Upon applying tectonic correction to each sitemean direction, the inclinations became slightly to moderately downward plunging and the grouping became worse (Fig. 7), that is, the overall unfolded mean direction was $\mathrm{D}=142.3^{\circ}, \mathrm{I}=22.1^{\circ}$ with $\alpha_{95}=24.9^{\circ}$. In contrast to gentle bedding of the Kukinaga Group, the strata of the Kumage Group are commonly affected by strong deformation. In the present case, the layers including sites 17 and 18 are overturned dipping almost $80^{\circ}$ to the east about a N30-35E strike, whilst those including sites 19, 20 and 22 show moderate bedding dips between $35^{\circ}$ and $60^{\circ}$ about a N30-55E strike. Applying the statistical analysis of MCFADDEN and JONES (1981) to those directions taken from layers with two principally different bedding attitudes, the left side of inequality in their paper became 6.174 when the unfolded directions were used and 0.071 when the in situ directions used. Comparison of these observed values with the critical value (1.714 for $\mathrm{N}=5$ ) calculated at the $95 \%$ confidence level led us to conclude that the hypothesis of a common true mean direction should be rejected for the former case and accepted for the latter. This implies that the magnetization acquisition postdated tectonic folding. Moreover, the in situ site-mean directions were comparable with prefolding directions of the Kukinaga Group, suggesting that at least the upper portions of the Kumage Group were remagnetized probably during the Middle Miocene when the Kukinaga Group was deposited.

Directions of low unblocking temperature component $\left(<250^{\circ} \mathrm{C}\right)$ were also determined for 77 Kumage Group specimens. The in situ directions show a cluster with a 
mean direction of $\mathrm{D}=11.6^{\circ}, \mathrm{I}=59.9^{\circ}$ and $\alpha_{95}=5.5^{\circ}$, while those after structural correction were considerably different from the present field direction; $\mathrm{D}=332.1^{\circ}, \mathrm{I}=7.6^{\circ}$ and $\alpha_{95}=7.8^{\circ}$. This strongly suggests that these components are recent overprints superposed on the high unblocking temperature components which had also been acquired after structural deformation.

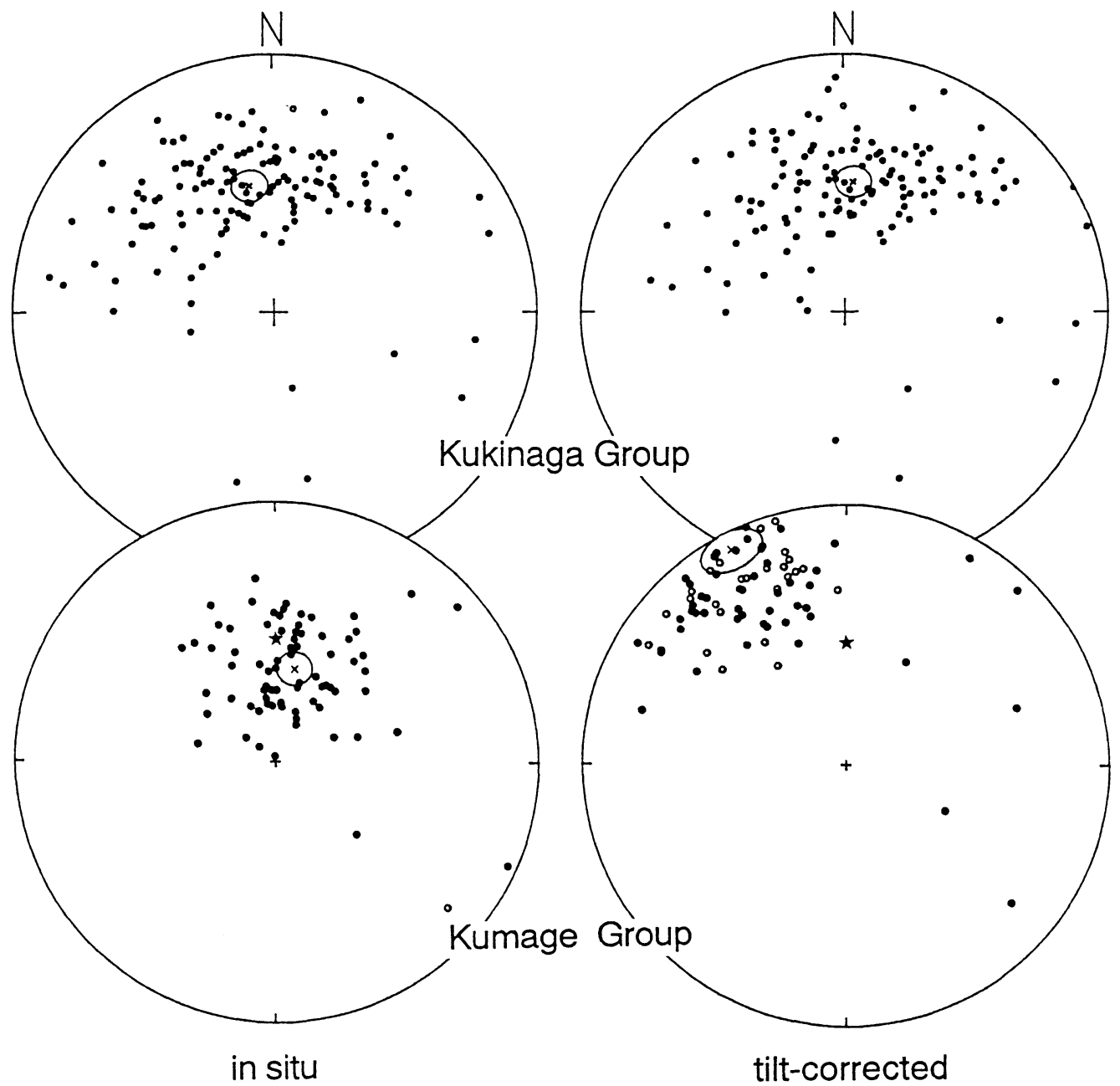

Fig. 8. Directions of magnetization components with lower unblocking or coercivity spectra, isolated using vector endpoints displaying univectorial trend during early steps of af or thermal demagnetization. Top, Kukinaga Group samples; Bottom, Kumage Group samples. Cross marks and ovals are mean directions and errors of $95 \%$ confidence. Star indicates expected dipole field direction. 

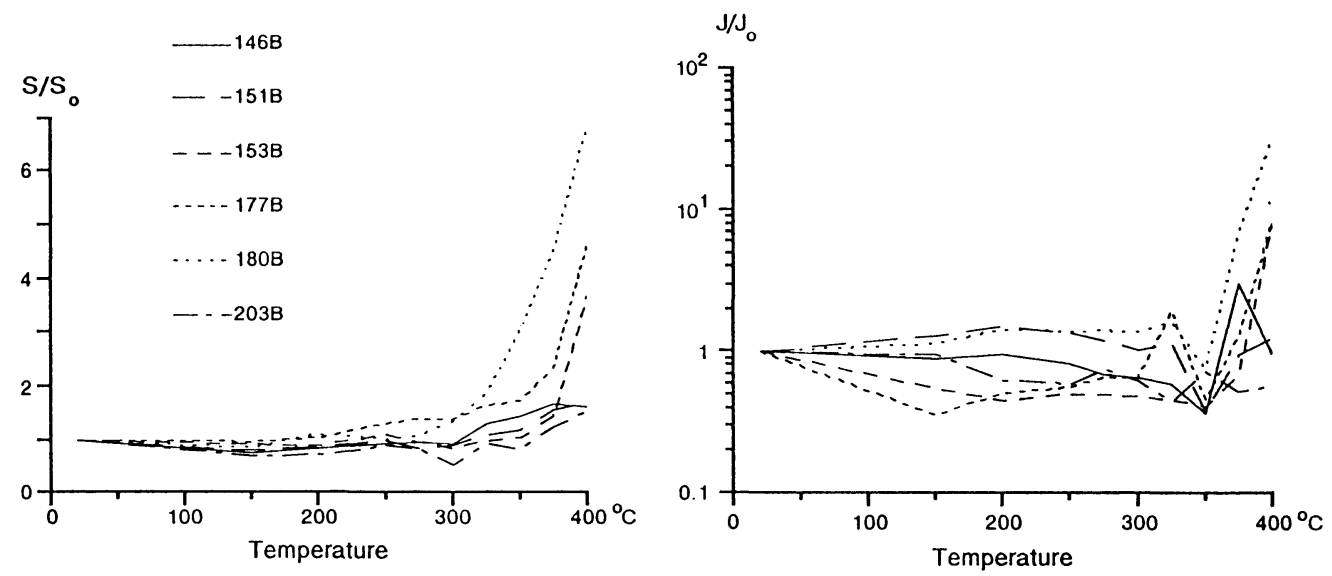

Fig. 9. Normalized bulk magnetic susceptibility (left) and magnetization intensity (right) after thermal treatment for representative specimens from the Kumage Group.

\section{Discussion}

According to the compilation by OTOFUJi et al. (1985a), the paleomagnetic direction for Southwest Japan has been indistinguishable from the axial dipole field direction since about $15 \mathrm{Ma}$ and the older directions show a $40^{\circ}$ to $50^{\circ}$ eastward deflection in declination. It has generally been accepted that the rapid swing in declination in the early Middle Miocene implies a CW rotation of Southwest Japan caused by the opening of the Japan Sea. The unfolded magnetization directions from the Kukinaga Group in Tanegashima Island show consistent CCW deflection. The mean direction $\left(\mathrm{D}=331.2^{\circ}\right.$, $\mathrm{I}=41.3^{\circ}$, and $\alpha_{95}=9.9^{\circ}$ ) is deflected from the paleomagnetic direction for Southwest Japan either before or after $15 \mathrm{Ma}$. The uppermost horizons of the Kukinaga Group yield microfossils of $\mathrm{N} 13$ to N15, which correspond to 10 to $12 \mathrm{Ma}$, according to the Cenozoic time scale by Bergaren et al. (1985). The lower age limit of the Kukinaga Group can be assessed by molluscs (Kadonosawa Fauna) occurring at the lower Kukinaga Group. According to CHINZEI (1986), the Kadonosawa Fauna corresponds to $\mathrm{N} 8$ to N9, ranging from about 15 to $16.5 \mathrm{Ma}$ (BERGGREN et al., 1985). Thus, the paleomagnetic directions from the Kukinaga Group show no systematic change in declination during the period at least between 12 and 15 Ma. Taking the Eurasian mean paleopole at $10 \mathrm{Ma}$ (IRVING and IRVING, 1982) as a reference, the expected dipole field direction at Tanegashima Island $\left(30.7^{\circ} \mathrm{N}, 131.0^{\circ} \mathrm{E}\right)$ is $\mathrm{D}=4.2^{\circ}, \mathrm{I}=51.9^{\circ}$. The paleomagnetic direction from the Kukinaga Group is deflected from this reference direction by $33.0^{\circ} \pm 10.7^{\circ}$ in declination and $10.6^{\circ} \pm 8.7^{\circ}$ in inclination. The errors of $95 \%$ confidence limits were computed using the method of DEMAREST (1983). The differences in declination and inclination are statistically significant. The difference in inclination may imply northward translation with respect to Eurasia which, however, seems to be not so convincing because the error is compatible with the inclination anomaly. The consistent paleomagnetic directions of the Kukinaga Group demonstrate that the Tanegashima Island undertook a CCW rotation about a vertical axis by about $30^{\circ}$ with respect to Eurasia during the last $10 \mathrm{Ma}$, after deposition of the Kukinaga Group. We would emphasize that the CCW rotation took place after the Japan Sea opening. Lack 
of distinct submarine faults in the vicinity of the island (MARITIme SAFETy AgEnCY, 1975) makes it unlikely that the rotation reflects local tectonism.

The pre-Miocene strata of Southwest Japan change the general strike by approximately $30^{\circ}$ in Southwest Kyushu (e.g., Hashimoto, 1962). Structural analysis (MurATA, 1987) revealed that the bend was caused by near-vertical folds of the preMiocene strata which had once trended more straight than at present. MurATA (1987) and KANO et al. (1990) insisted that this distinct bend in geological structure was formed by the CW rotation of Southwest Japan, with South Kyushu and north Ryukyu arc fixed, contemporaneous with the Japan Sea opening at about 15 Ma. However, there is no definite geological evidence supporting their hypothesis. They proposed the synchronism of the bend with the Southwest Japan rotation, based only on that the deformed pre-Miocene strata are intruded by the Middle Miocene granitoids (13 to $14 \mathrm{Ma}$; ShibATA, 1978). Their interpretation seems invalid because several westerly deflected remanent directions were reported from the Middle Miocene Osumi granite in South Kyushu (IsHIKAWA and TORII, 1986). Although this granite does not directly intrude the bent pre-Miocene strata, the mean direction was $\mathrm{D}=314.7^{\circ}, \mathrm{I}=45.7^{\circ}, \alpha_{95}=21.4^{\circ}$, which is in statistical agreement with that of Tanegashima Island. This may imply that not only Tanegashima Island but South Kyushu, along with some intrusives, experienced the CCW rotation. It is uncertain, because of the lack of paleomagnetic data, whether the north Ryukyu islands south of Tanegashima Island suffered CCW rotation in the same manner. We insist that the amount of the bend in South Kyushu agrees well with the CCW rotation angle of Tanegashima Island and that the rotation was later than the Japan Sea opening. It is thus more plausible that the bend was caused not by the Japan Sea opening but by the CCW rotation of South Kyushu, including Tanegashima Island, with respect to Southwest Japan during the last 10 Ma.

Based on paleomagnetism of the south Ryukyu arc, MIKI et al. (1990) concluded that the southern part of the arc has rotated CW by $19^{\circ}$ with respect to Eurasia during the past $10 \mathrm{Ma}$. They proposed that the $\mathrm{CW}$ rotation was caused by a wedge-shaped back-arc opening of the southern part of the Okinawa trough, as the CW rotation of Southwest Japan is attributed to the Japan Sea opening. Accordingly, it might be suspected that the observed CCW rotation of Tanegashima Island could be ascribed to the opening of the northern part of the Okinawa trough. This seems unrealistic, however, because the evolutionary stage of back-arc basin formation is less advanced in the northern part of the Okinawa trough, where the basin development is only in a rifting stage, than in the southern and middle parts in an incipient spreading stage (Kimura et al., 1986; Letouzey and Kimura, 1986; Sibuet et al., 1987). Viallon et al. (1986) explained the opening of the Okinawa trough by a retreating trench model with anchor points due to the collision in Taiwan and the buoyant subduction of the Kyushu-Palau ridge. Their numerical analysis predicts CCW rotation for the north Ryukyu arc and CW rotation for the south Ryukyu arc. The CW rotation was exemplified by paleomagnetic studies (JARRARD and SASAJIMA, 1980; MiKI et al., 1990). However, the amount of CCW rotation predicted for the north Ryukyu arc is only negligible $\left(<10^{\circ}\right)$. This means that the trench retreat model cannot fully account for the CCW rotation of Tanegashima Island.

An alternative explanation for the CCW rotation of Tanegashima Island is the collision-related deformation of an island arc as proposed originally by VOGT (1973). MCCABE (1984) pointed out that anomalous paleomagnetic declinations were observed 
from various segments of western Pacific island arcs in the vicinity of the collision zones and could be explained by tectonic rotation of the arc. Applying this model to the present case, the CCW rotation of Tanegashima Island could have resulted from the collision, or the buoyant subduction, of the Kyushu-Palau ridge with the junction of the southwest Japan and the north Ryukyu arcs (Fig. 10). In addition, indentation followed by the collision, or strong coupling with the overriding plate produced by the buoyant subduction, may have given rise to the bend of pre-Miocene strata in South Kyushu. We assume in this model that, prior to the Middle Miocene, Honshu and Kyushu had more linear configuration than at present. We suspect that North and South Kyushu rotated CW along with Honshu at the Middle Miocene. Paleomagnetic data from the Cretaceous granite in North Kyushu support this (ITO and TOKIEDA, 1986). No reliable paleomagnetic direction has been reported from the pre-Middle Miocene rocks in South Kyushu, but geological studies (e.g., KANO et al., 1990) suggest that the pre-Middle Miocene terranes in South Kyushu trended more straight than present. Although no primary magnetic component was detected from the Paleogene Kumage Group, its geological structure similar to that in South Kyushu suggest that Tanegashima Island experienced the same tectonism as in South Kyushu. It is after the cessation of the $\mathrm{CW}$ rotation when the Kukinaga Group began to accumulate. In the Late Miocene or later, a CCW rotation took place in Tanegashima Island and South Kyushu.

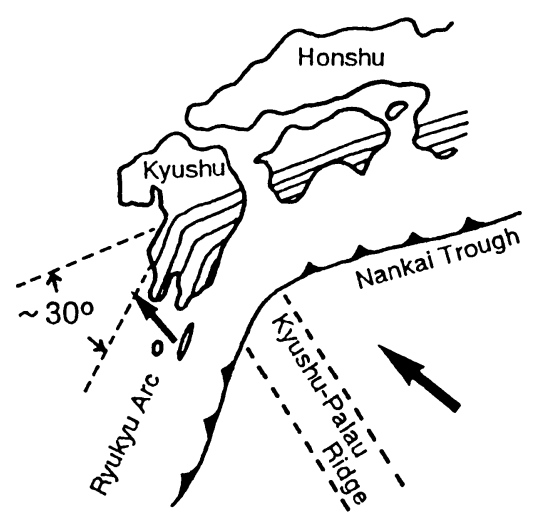

Present

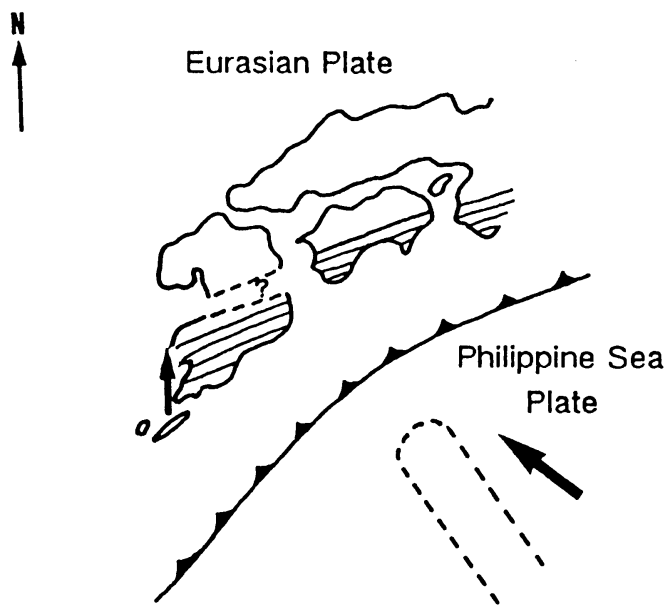

Late Miocene

Fig. 10. A model illustrating that the counter-clockwise (CCW) rotation of South Kyushu, including Tanegashima Island, and the bend of pre-Miocene strata resulted from collision, or buoyant subduction, of the Kyushu-Palau ridge since the Late Miocene. Honshu and Kyushu rotated together clockwise at the Middle Miocene and, afterwards, only Tanegashima Island and South Kyushu rotated CCW by $30^{\circ}$, which caused the bend of pre-Miocene strata in South Kyushu. Small arrow denotes paleomagnetic direction of Tanegashima Island, representing the post-Middle Miocene CCW rotation. The boundary between North and South Kyushu is speculative. Position of the Kyushu-Palau ridge at the Late Miocene was determined extrapolating the present motion of the Philippine Sea plate relative to Eurasia, as denoted by solid arrow directing N55W by SENO (1977). 
The collision-deformed model may require a compressional stress field in South Kyushu during the period of its CCW rotation. Although present stress field in central Kyushu is N-S extension (e.g., TADA, 1985), we predict that a compressional field was dominant in South Kyushu during some period after the Late Miocene. There is no geological evidence concerning the stress field for this period in geological past. Extensive, combined paleomagnetic and geologic studies from various regions in South Kyushu are necessary in order to test the validity of our interpretation.

\section{Conclusions}

1) Reliable paleomagnetic directions were determined for 11 out of 15 stratigraphic levels from the Middle Miocene Kukinaga Group in Tanegashima Island. Eight of the 11 directions were of reversed polarity and three were of normal polarity. The unfolded formation-mean direction was $\mathrm{D}=331.2^{\circ}, \mathrm{I}=41.3^{\circ}$, and $\alpha_{95}=9.9^{\circ}$. Five of seven horizons from the Paleogene Kumage Group yielded stable magnetization components of reversed polarity which, however, were not regarded as primary because of a negative fold test.

2) The mean paleomagnetic direction from the Kukinaga Group is deflected counterclockwise $(\mathrm{CCW})$ by $33.0^{\circ} \pm 10.7^{\circ}$ from the direction computed using the paleomagnetic pole of Eurasia at $10 \mathrm{Ma}$. It follows that Tanegashima Island rotated approximately $30^{\circ} \mathrm{CCW}$ with respect to not only Eurasia but Southwest Japan since the Late Miocene.

3) Intra-arc deformation produced by collision or buoyant subduction of the Kyushu-Palau ridge may account for the rotation. It seems likely that the bend of pre-Miocene strata in South Kyushu resulted from such deformation.

We thank Dr. A. Hayashida and an anonymous reviewer for constructive comments and suggestions. This study was supported by Grant-in-Aid for Scientific Research, the Ministry of Education, Science and Culture (No. 62420015), and by Dynamics and Evolution of the Lithosphere Project (DELP) in 1988 and 1989.

\section{REFERENCES}

Berggren, W. A., D. V. Kent, J. J. Flynn, and J. A. Van Couvering, Cenozoic geochronology, Geol. Soc. Am. Bull., 96, 1407-1418, 1985.

Blow, W. H., Late Middle Eocene to recent planktonic foraminiferal biostratigraphy, in Proc. 1st Int. Conf. Planktonic Fossils, Geneva, pp. 199-422, 1969.

ChinzeI, K., Opening of the Japan Sea and marine biogeography during the Miocene, J. Geomag. Geoelectr., 38, 487-494, 1986.

Demarest, H. H. Jr., Error analysis for the determination of tectonic rotation from paleomagnetic data, J. Geophys. Res., 88, 4321-4328, 1983.

Hasнimoто, I., Geological succession and structure of the undated strata in the Hokusatsu district, Kagoshima Prefecture, Rep. Earth Sci. Dept. Gen. Educ., Kyushu Univ., 8, 47-62, 1962.

Hatta, A., The foraminiferal assemblage from Kukinaga Group and Masuda Formation in Tanegashima, Nansei Islands, South Kyushu, Japan, Bull. Fac. Educ., Kagoshima Univ. (Nat. Sci.), 40, 25-44, 1988.

Hayasaka, S., Molluscan fauna of the Kukinaga Group in Tane-ga-shima, South Kyushu, Japan, Rep. Fac. Sci. Kagoshima Univ. (Earth Sci. Biol.), 2, 33-52, 1969.

Hayasaka, S., Geology of Tane-ga-shima, Modern Geology, 12, 169-183, 1988. 
HaYASAKa, S., Y. FukUda, and A. Hayama, Discovery of molluscan fossils and the paleoenvironmental aspects of the Kumage Group in Tane-ga-shima, South Kyushu, Japan, Prof. Saburo Kanno Mem. Vol., pp. 59-70, 1980.

HAYASHidA, A., Timing of rotational motion of Southwest Japan inferred from paleomagnetism of the Setouchi Miocene Series, J. Geomag. Geoelectr., 38, 295-310, 1986.

HaYAshidA, A. and Y. ITO, Paleoposition of Southwest Japan at $16 \mathrm{Ma}$ : implication from paleomagnetism of the Miocene Ichishi Group, Earth Planet. Sci. Lett., 68, 335-342, 1984.

Hirooka, K., H. Sakai, T. Takahashi, H. Kinoto, and A. Takeuchi, Tertiary tectonic movement of Central Japan inferred from paleomagnetic studies, J. Geomag. Geoelectr., 38, 311-323, 1986.

Irving, E. and G. A. Irving, Apparent polar wander paths, Carboniferous through Cenozoic and the assembly of Gondowana, Geophys. Surv., 5, 141-188, 1982.

ISHIKAWA, N. and T. TAGAMI, Paleomagnetism and fission-track geochronology on the Goto and Tsushima Islands in the Tsushima strait area: implications for the opening mode of the Japan Sea, J. Geomag. Geoelectr., 43, 229-253, 1991.

IsHIKAWA, N. and M. TORII, Westerly deflected remanent direction of the Middle Miocene granite from the Osumi Peninsula, Rock Magn. Paleogeophys., 13, 8-11, 1986.

Ishikawa, N., M. ToRII, and K. KogA, Paleomagnetic study of the Tsushima Islands, southern margin of the Japan Sea, J. Geomag. Geoelectr., 41, 797-811, 1989.

Ito, H. and K. ToKieda, Tilting movements of the Japanese Islands inferred from Cretaceous and Early Tertiary paleomagnetic data, J. Geomag. Geoelectr., 38, 361-386, 1986.

Ito, H., K. TOKIEDA, and Y. Notsu, Paleomagnetic study of Miocene granitic rocks in the Goto islands and Tsushima, Mem. Fac. Sci. Shimane Univ., 14, 85-93, 1980.

Iтон, Y., Differential rotation of the eastern part of Southwest Japan inferred from paleomagnetism of Cretaceous and Neogene rocks, J. Geophys. Res., 93, 3401-3411, 1988.

JARrard, R. D. and S. SASAJIMA, Paleomagnetic synthesis for Southeast Asia: constraints on plate motions, in The tectonics and geologic evolution of Southeast Asian Seas and Islands, Part 1, edited by D. E. Hayes, Geophys. Monogr., Am. Geophys. Union, 23, 293-316, 1980.

Kano, K, K. Kosaka, A. Murata, and S. YANAI, Intra-arc deformations with vertical rotation axes: the case of the pre-Middle Miocene terranes of Southwest Japan, Tectonophys., 176, 333-354, 1990.

Kimura, M., I. Kaneoke, Y. Kato, S. Yamamoto, I. Kushiro, H. Tokuyama, H. Kinoshita, N. Isezaki, H. MASAKI, A. Oshida, S. UyedA, and T. W. C. Hilde, Report on DELP 1984 cruises in the Middle Okinawa Trough. Part V: Topography and geology of the central grabens and their vicinity, Bull. Earthq. Res. Inst., Univ. Tokyo, 61, 269-310, 1986.

Kirschvink, J. L., The least-squares line and plane and the analysis of paleomagnetic data, Geophys. J. R. Astron. Soc., 62, 699-719, 1980.

Kodama, K., Paleomagnetic study of the Upper Cretaceous Izumi strike-slip basin along the Median Tectonic Line in Southwest Japan, in Deep Structure and Past Kinematics of Accreted Terranes, edited by J. Hillhouse, Geophys. Monogr., 50, pp. 239-248, Am. Geophys. Union, 1989.

Kodama, K., Magnetostratigraphy of the Izumi Group along the Median Tectonic Line in Shikoku and Awaji Islands, Southwest Japan, J. Geol. Soc. Jpn., 96, 265-278, 1990 (in Japanese with English abstract).

KodAma, K. and T. BABA, Reconnaissance magnetostratigraphy of Upper Cretaceous-Paleogene deposits in Amakusa-shimojima, Western Kyushu, Japan, Mem. Fac. Sci. Kochi Univ., Ser. E, 9, $1-10,1988$.

Kodama, K., A. Taira, M. Okamura, and Y. Saito, Paleomagnetism of the Shimanto belt in Shikoku, Southwest Japan, in Accretion Tectonics in the Circum-Pacific Regions, edited by M. Hashimoto and S. Uyeda, pp. 231-241, Terra Sci. Pub., Tokyo, 1983.

Letouzey, J. and M. Kimura, The Okinawa trough: genesis of a back-arc basin development along a continental margin, Tectonophys., 125, 209-230, 1986.

Maritime SAFETy AGEnCY, Vicinity of Tane-Ga-Sima, in Basic Maps of the Sea in Continental Shelf Areas of Japan, 1975.

MCCABE, R., Implications of paleomagnetic data on the collision related bending of island arcs, Tectonics, 3, 409-428, 1984.

McFadden, P. L. and D. L. Jones, The fold test in paleomagnetism, Geophys. J. R. Astron. Soc., 67, 53-58, 1981. 
MCFADDEN, P. L. and M. W. MCElhinNy, The combined analysis of remagnetization circles and direct observations in palaeomagnetism, Earth Planet. Sci. Lett., 87, 161-172, 1988.

Miki, M., T. Matsuda, and Y. OtofuJI, Opening mode of the Okinawa Trough: paleomagnetic evidence from the South Ryukyu Arc, Tectonophys., 175, 335-347, 1990.

Murata, A., Conical folds in the Hitoyoshi Bending, South Kyushu, formed by the clockwise rotation of the Southwest Japan Arc, J. Geol. Soc. Japan, 93, 91-105, 1987.

OKada, H., K. ОкABE, K. SuzuKI, and K. NAKASEKo, Radiolarian fossil assemblages of the Kumage Group (Shimanto Belt) in Tanegashima, Southwest Japan, News Osaka Micropaleont. Spec. Vol., No. 5, 409-413, 1982 (in Japanese with English abstract).

ОтоFUJi, Y. and T. MATSUDA, Paleomagnetic evidence for the clockwise rotation of Southwest Japan, Earth Planet. Sci. Lett., 62, 349-359, 1983.

Otofuji, Y. and T. MAtsuda, Amount of clockwise rotation of Southwest Japan-fan shape opening of the southwestern part of the Japan Sea, Earth Planet. Sci. Lett., 85, 289-301, 1987.

Otofuji, Y., A. HAYASHIDA, and M. TORII, When was the Japan Sea opened?: paleomagnetic evidence from Southwest Japan, in Formation of Active Ocean Margins, edited by N. Nasu, S. Uyeda, I. Kushiro, K. Kobayashi, and H. Kagami, pp. 551-566, Terra Sci. Pub., Tokyo, 1985a.

Otofuji, Y., T. Matsuda, and S. NoHDA, Paleomagnetic evidence for the Miocene counter-clockwise rotation of Northeast Japan: rifting process of the Japan Arc, Earth Planet. Sci. Lett., 75, 265-277, 1985b.

Otofuji, Y., T. Matsuda, and S. NohDA, Opening mode of the Japan Sea inferred from the paleomagnetism of the Japan Arc, Nature, 317, 603-604, 1985c.

Seno, T., The instantaneous rotation vector of the Philippine Sea plate relative to the Eurasian plate, Tectonophys., 42, 209-226, 1977.

ShiBata, K., Contemporaneity of Tertiary granites in the outer zone of Southwest Japan, Bull. Geol. Surv. Jpn., 29, 551-554, 1978 (in Japanese with English abstract).

Sibuet, J.-C., J. Letouzey, F. Barrier, J. Charvet, J.-P. Foucher, T. W. C. Hilde, M. Kimura, L.-Y. Chiao, B. Marsset, C. Muller, and J.-F Stephan, Back arc extension in the Okinawa Trough, J. Geophys. Res., 92, 14041-14063, 1987.

TADA, T., Spreading of the Okinawa Trough and its relation to the crustal deformation in the Kyushu (2), J. Seismol. Soc. Jpn., 38, 1-12, 1985 (in Japanese with English abstract).

Taira, A., H. OKada, J. H. McD. Whitaker, and A. J. Smith, The Shimanto Belt of Japan: Cretaceous-Lower Miocene active margin sedimentation, in Trench-Forearc Geology, Geol. Soc. London Spec. Publ., No. 10, edited by J. K. Leggett, pp. 5-26, 1982.

TANEDA, S. and K. KINOSHITA, An alkaline rock body in Tanegashima Island, South Kyushu, Japan, Bull. Volcan. Soc. Japan, 2nd Ser., 17, 88-97, 1972 (in Japanese with English abstract).

Tosha, T. and Y. Hamano, Paleomagnetism of Tertiary rocks from the Oga Peninsula and the rotation of Northeast Japan, Tectonics, 7, 653-662, 1988.

Viallon, C., P. HuChON, and E. BARrier, Opening of the Okinawa basin and collision in Taiwan: a retreating trench model with lateral anchoring, Earth Planet. Sci. Lett., 80, 145-155, 1986.

Vogt, P. R., Subduction of aseismic ridges, Nature, 241, 189-192, 1973.

YAMAZAKI, T., Paleomagnetism of Miocene sedimentary rocks around Matsushima Bay, Northeast Japan and its implication for the time of the rotation of Northeast Japan, J. Geomag. Geoelectr., 41, 533-548, 1989.

Yoneda, S. and A. Inamatsu, Stratigraphy and geologic structure of the Shimanto supergroup in the Hokusatsu district, Kagoshima Prefecture, South Kyushu, Japan, J. Geol. Soc. Jpn., 93, $881-895,1987$.

ZiJdeRVELd, J. D. A., A.C. demagnetization of rocks: analysis of results, in Methods in Palaeomagnetism, edited by D. W. Collinson, K. M. Creer, and K. S. Runcorn, pp. 254-268, Elsevier, Amsterdam, 1967. 